\title{
ZALEŻNOŚĆ POMIĘDZY SZARĄ STREFĄ A PODATKAMI ANALIZA PRZEKROJOWA DLA KRAJÓW OECD
}

\section{Wstęp}

Szara strefa stanowi znaczną część PKB wielu krajów na świecie. Wywiera zatem spory wpływ na funkcjonowanie całych gospodarek i kształtowanie się różnych wskaźników makroekonomicznych. Pomimo licznych badań prowadzonych nad zjawiskiem szarej strefy, jej nieuchwytność i trudność pomiaru sprawia, że ciągle niełatwo jest wskazać jednoznacznie główne siły napędowe gospodarki nieformalnej. Celem pracy jest zbadanie zależności pomiędzy łącznym obciążeniem podatkowym oraz poszczególnymi rodzajami opodatkowania a rozmiarami szarej strefy.

Układ niniejszej pracy jest następujący. W części pierwszej zostanie przedstawione zjawisko szarej strefy gospodarki i jego szacunki dla wybranych krajów OECD. W części następnej omówimy i skomentujemy dotychczasowe artykuły, w których przedstawiono badania dotyczące zależności pomiędzy szarą strefą a wielkością obciążeń podatkowych. W części trzeciej omówimy ideę badania oraz opiszemy źródła używanych danych i ich przygotowanie do obliczeń. Część czwarta zawierać będzie próbę analizy statystycznej zależności pomiędzy różnymi rodzajami opodatkowania (w szczególności rozróżnienia dokonamy na podatki pośrednie i bezpośrednie) a rozmiarami szarej strefy gospodarki w krajach OECD. Całość zamknie podsumowanie i wyciągnięcie wniosków z przeprowadzonej analizy.

\section{Szara strefa gospodarki}

Pod pojęciem szarej strefy gospodarki (szarej gospodarki, gospodarki nieformalnej ${ }^{1}$ ) rozumiemy wszelką aktywność gospodarczą, która przyczynia się do wytworzenia PKB, a która pozostała niezarejestrowana ${ }^{2}$. A zatem do szarej

* Doktorantka, Katedra Ekonometrii, Wydział Ekonomiczno-Socjologiczny UŁ.

${ }^{1} \mathrm{~W}$ literaturze znaleźć można wiele innych określeń szarej strefy, przykładowe synonimy wymieniane są m.in. w pracach T. Smuga i in., Metodologia badań szarej strefy na rynku ustug turystycznych, Instytut Koniunktury i Cen Handlu Zagranicznego, Warszawa, 2005, oraz K. Patera $\mathrm{i}$ in., Projekt Przyczyny pracy nierejestrowanej, jej skala, charakter i skutki społeczne, Warszawa, CBOS, IPiSS, 2007.

${ }^{2}$ Por. T. Smuga i in., Metodologia badań szarej strefy... 
gospodarki zaliczyć należy zarówno działalność legalną ukrytą (zatajanie części produkcji i usług, które nie są zabronione przez prawo), jak i aktywność gospodarczą nielegalną (produkcja dóbr i świadczenie usług, które są zakazane, np. sprzedaż narkotyków, prostytucja). Podobną definicję szarej strefy przyjmuje GUS, jednak ze względu na trudność pomiaru aktywności nielegalnej, w statystykach uwzględniana jest jedynie legalna działalność nierejestrowana, zgodnie z praktyką innych krajów UE. Według zaleceń systemu rachunków narodowych SNA 93 do szarej strefy powinna być wliczana działalność nielegalna, w ramach której dochodzi do wymiany dóbr lub świadczenia usług za zgodą obu stron transakcji. Wiąże się to jednak z trudnością dokonania pomiaru tej działalności. Oprócz tego prowadzi to do kolejnego problemu, bowiem ze względu na zróżnicowanie przepisów prawnych i ich zmienność w czasie kłopotliwe staje się porównywanie szacunków tak obliczonych rozmiarów szarej strefy pomiędzy różnymi krajami oraz badanie ich zmienności na przestrzeni różnych lat. W związku z tym $w$ analizie zjawiska szarej strefy w krajach OECD posługiwać się będziemy statystykami zawierającymi jedynie część legalną nierejestrowaną ${ }^{3}$ szarej gospodarki.

Według najświeższych szacunków F. Schneidera wykonanych metodą MIMIC rozmiary szarej strefy gospodarki (mierzone jako \% PKB) w latach 20032012 w 36 krajach OECD (z wyłączeniem Chile, Islandii, Izraela, Korei Płd., Meksyku, z włączeniem dodatkowo Bułgarii, Cypru, Łotwy, Litwy, Malty, Rumunii, Chorwacji) kształtowały się na poziomie od 8\% do 33\% PKB danego kraju. Największe rozmiary szarej strefy odnotowano w Europie ŚrodkowoWschodniej (głównie: Bułgaria, Estonia, Litwa, Rumunia, Chorwacja, Turcja), zdecydowanie niższe w Europie Zachodniej i pozostałych wysoko rozwiniętych krajach OECD (m.in. Stany Zjednoczone, Szwajcaria, Luksemburg, Austria, Holandia, Japonia, Nowa Zelandia). Niektórzy autorzy zwracają uwagę na fakt ${ }^{4}$, że wysoki poziom szarej gospodarki w krajach postkomunistycznych może być związany z relatywnie wysokim przyzwoleniem społecznym na działalność nierejestrowaną, odziedziczonym po gospodarce centralnie planowanej.

Na przestrzeni lat 2003-2012 zaobserwować można wyraźną dynamikę spadkową rozmiarów szarej strefy we wszystkich analizowanych krajach. Wyjątek stanowi jedynie rok 2009, w którym poziom gospodarki nieformalnej nieznacznie wzrósł. Przypuszcza się, że jest to związane z kryzysem gospodarczym, który ze względu na wzrost bezrobocia i niekorzystną koniunkturę gospodarczą wymusił zwiększoną działalność nierejestrowaną. Obliczone średnie rozmiary szarej strefy w latach 2003-2012 występujące we wskazanych krajach OECD przedstawiono w tabeli 1.

\footnotetext{
${ }^{3}$ Definicja pochodzi z pracy F. Schneider, The shadow economy and shadow economy labor force: What do we (not) know?, „Forschungsinstitut zur Zukunft der Arbeit” 2011, no. 5769, s. 6.

${ }^{4}$ T. Smuga i in., Metodologia badań szarej strefy..., s. 13.
} 
Tabela 1. Przeciętne rozmiary szarej strefy w latach 2003-2012 w krajach OECD (z wyłączeniem Chile, Islandii, Izraela, Korei Płd., Meksyku)

\begin{tabular}{|l|c|l|c|l|c|}
\hline \multicolumn{1}{|c|}{ Kraj } & $\begin{array}{c}\text { Szara strefa } \\
\% \text { PKB }\end{array}$ & \multicolumn{1}{|c|}{ Kraj } & $\begin{array}{c}\text { Szara strefa } \\
\% \text { PKB }\end{array}$ & \multicolumn{1}{|c|}{ Kraj } & $\begin{array}{c}\text { Szara strefa } \\
\% \text { PKB }\end{array}$ \\
\hline Austria & 9,1 & Irlandia & 13,5 & Słowacja & 16,9 \\
\hline Belgia & 18,6 & Włochy & 22,9 & Szwecja & 16,0 \\
\hline Bułgaria & 33,4 & Lotwa & 28,0 & Wielka Brytania & 11,1 \\
\hline Cypr & 27,0 & Litwa & 30,1 & Chorwacja & 30,6 \\
\hline Czechy & 17,5 & Luksemburg & 9,1 & Norwegia & 16,0 \\
\hline Dania & 15,1 & Malta & 26,3 & Szwajcaria & 8,4 \\
\hline Estonia & 29,6 & Holandia & 10,7 & Turcja & 29,4 \\
\hline Finlandia & 15,0 & Polska & 26,1 & Australia & 11,4 \\
\hline Francja & 12,3 & Portugalia & 20,1 & Kanada & 13,1 \\
\hline Niemcy & 14,8 & Rumunia & 30,7 & Japonia & 9,6 \\
\hline Grecja & 25,8 & Słowenia & 25,0 & Nowa Zelandia & 10,3 \\
\hline Węgry & 23,7 & Hiszpania & 20,1 & Stany Zjednoczone & 7,6 \\
\hline
\end{tabular}

Źródło: F. Schneider, The shadow economy and shadow economy labor force: What do we (not) know?, „Forschungsinstitut zur Zukunft der Arbeit” 2011, Nr. 5769.

\section{Obciążenia podatkowe i szara strefa}

Jedną z najczęściej wymienianych determinant szarej strefy gospodarki są obciążenia podatkowe. W literaturze ekonomicznej znaleźć można liczne przykłady artykułów, w których zawarto analizę powyższej zależności. W niektórych przedstawiono badania ankietowe reprezentatywnej próby społeczeństwa. M. Kozyra-Cybulska i współpracownicy ${ }^{5}$, opisują wyniki wywiadów z członkami gospodarstw domowych odnośnie do motywów aktywności w szarej strefie, które zostały przeprowadzone w województwie podkarpackim w 2009 r. Na pytanie „Jakie są Pana(i) zdaniem główne przyczyny prowadzenia działalności nierejestrowanej?” najczęstszą odpowiedzią, którą wskazało 26\% badanych respondentów, były zbyt wysokie podatki i składki społeczne. Podobne badania przeprowadzone zostały dla wszystkich krajów UE w ramach cyklicznego programu badań opinii publicznej - Eurobarometru w 2007 r. $^{6}$ Najczęstszymi odpowiedziami udzielanymi przez przeciętnego Europejczyka na pytanie What are the reasons for doing undeclared work? były zbyt niskie wynagrodzenia w sferze rejestrowanej (41\% wskazań) oraz duże obciążenia podatkowe i składki na ubezpieczenia społeczne (32\% wskazań). Co ciekawe,

${ }^{5}$ M. Kozyra-Cybulska i in., Badanie warunków i jakości życia oraz zachowań ekonomicznych w gospodarstwach domowych, działalność nierejestrowana, PTS, Rzeszów, 2010.

${ }^{6}$ Special Eurobarometer, Undeclared Work in the European Union, European Commission, Brussels 2007, s. 99. 
jeżeli przyjrzymy się odrębnym statystykom poszczególnych krajów UE, to na obciążenia podatkowe najbardziej narzekają Belgowie, Duńczycy, Litwini Węgrzy, Maltańczycy i Szwedzi (ponad 50\% respondentów), zaś najmniej Bułgarzy i Słoweńcy (poniżej 20\% wskazań). Podsumowanie różnych badań ilościowych dotyczących sił napędowych szarej strefy gospodarki znaleźć można w pracy F. Schneidera ${ }^{7}$. Analiza wyników 28 badań pozwala stwierdzić, iż istnieje kilka czynników, które w 76-94\% wpływają na zmiany rozmiarów szarej gospodarki. Kluczowy z nich jest wzrost obciążeń podatkowych i składek na ubezpieczenia społeczne, który w 35-38\% oddziałuje na zmienność gospodarki nieformalnej.

Pomimo często wskazywanej zależności pomiędzy szarą strefą a obciążeniami podatkowymi, relacja ta wzbudza obecnie wiele wątpliwości. We wspominanej już pracy Schneider zaznacza, że pomimo tego, że obciążenia podatkowe traktowane są jako jeden z głównych czynników determinujących rozmiary szarej strefy, to sama gruntowna reforma podatkowa polegająca na obniżeniu głównych stawek podatkowych nie doprowadzi do znacznego spadku rozmiarów gospodarki nieformalnej. Może, co najwyżej, ustabilizować je na określonym poziomie i zapobiec ich dalszemu powiększaniu się. Korzyści płynące z działalności nierejestrowanej i wytworzone sieci zależności są bowiem zbyt silne i zbyt złożone, aby samo obniżenie obciążeń podatkowych mogło zniwelować działalność w szarej strefie. Jako przykład kraju, w którym gruntowne reformy podatkowe nie przyczyniły się do znacznego obniżenia rozmiarów szarej gospodarki podawana jest Austria. Tym niemniej, Schneider podaje też przykłady badań, które wskazują na wyraźną, istotną statystycznie dodatnią zależność pomiędzy szarą strefą a podatkami (np. w krajach skandynawskich).

M. Kabaj ${ }^{8}$ opisuje prostą analizę statystyczną 10 krajów Europy Centralnej i Wschodniej, z której wynika, że istnieją kraje o relatywnie niskich stawkach podatków bezpośrednich (PIT i CIT), np. Słowenia, w których szara strefa ukształtowała się na relatywnie wysokim poziomie. Dodatkowo wskazuje też na Bułgarię i Rumunię - kraje o najwyższych rozmiarach gospodarki nieformalnej, w których obciążenia podatkowe zbliżone są do stawek podatkowych w innych gospodarkach. M. Kabaj opisuje też zależność pomiędzy szarą strefą a pośrednimi kosztami pracy w 23 krajach UE w 2004 r. Wszystkie państwa podzielono na dwie grupy - na kraje o wysokim poziomie szarej gospodarki i kraje o niskiej szarej strefie. Na podstawie analizy danych stwierdzono, że przeciętne koszty pracy w obu grupach są niemal identyczne - wynoszą $37,1 \% \mathrm{w}$ pierwszej grupie i $37,9 \%$ w grupie drugiej. Oznaczać to może, iż istnieje wiele innych czynników pozapodatkowych (i parapodatkowych) wpływających na rozmiary szarej strefy.

${ }^{7}$ F. Schneider, Shadow economies and corruption all over the World: What do we really know?, Kiel Institute for the World Economy, Economics Discussion Papers 2007, no. 9.

${ }^{8}$ M. Kabaj, Praca nierejestrowana we wspótczesnej literaturze ekonomicznej, ,Polityka Społeczna" 2009, nr 10, s. 7. 
Pomiaru korelacji pomiędzy obciążeniami podatkowymi a szarą strefą na dużo większej próbie 118 krajów w okresie 1996-2004 dokonał w swojej pracy S.B. Aruoba ${ }^{9}$. Jako zmienne reprezentujące obciążenia podatkowe przyjął przeciętną stawkę podatkową (wyrażoną $\mathrm{w} \%$ ) oraz przychody podatkowe (wyrażone jako \% PKB), zaś szara strefa podana została jako \% PKB. Szacunki korelacji prowadzą do zaskakujących wniosków - w obu przypadkach otrzymano korelację ujemną $(-0,5$ dla stawki podatku oraz $-0,34$ dla przychodów podatkowych). A zatem wysokim obciążeniom podatkowym towarzyszą niskie rozmiary szarej strefy i na odwrót. Uzyskaną współzależność S.B. Aruoba thumaczy oddziaływaniem innych czynników na rozmiary szarej strefy. Sugeruje, że obecnie to nie obciążenia podatkowe, ale jakość instytucji jest główną siłą napędową szarej gospodarki. W związku z tym dokonuje pomiaru korelacji pomiędzy instytucjami (mierzonej praworządnością) a gospodarką nieformalną, otrzymując wyraźną zależność ujemną na poziomie $-0,72$. A zatem, zdaniem Aruoby, zamiast skupiać się na podatkach, rządzący powinni zadbać przede wszystkim o jakość instytucji w celu ograniczenia szarej strefy gospodarki.

Na bardzo ciekawą zależność zwraca uwagę w swojej pracy G. Gołębiow$\mathrm{ski}^{10}$. Powołując się na badania przeprowadzone w Nowej Zelandii obejmujące lata 1969-1994 wysnuwa wniosek o zróżnicowanym wpływie różnych rodzajów podatków na szarą strefę. Przesunięcie części opodatkowania na rzecz podatków pośrednich (bez obniżenia łącznego obciążenia podatkowego) prowadzi do widocznego spadku rozmiarów szarej strefy. Jednak ów spadek nie jest tak duży, jaki można by było uzyskać wyraźnie obniżając łączne opodatkowanie bez zmiany wielkości udziałów poszczególnych podatków. Co więcej, obniżenie przychodów podatkowych prowadzi do ograniczenia rozmiarów szarej strefy, jednak nie jest to zależność liniowa i od pewnego poziomu opodatkowania spadki wielkości gospodarki nieformalnej stają się coraz mniejsze.

Analizę zależności pomiędzy podatkami a szarą strefą dla Polski za lata 1995-2006 przeprowadził S. Cichocki ${ }^{11}$. W pracy dokonano rozróżnienia pomiędzy różnymi rodzajami podatków. Okazało się, iż podniesienie przeciętnej stawki podatków pośrednich prowadzi do wzrostu rozmiarów szarej gospodarki. Podniesienie natomiast stawki PIT doprowadziło do obniżenia rozmiarów szarej strefy. Co ciekawe, gdy w stawce PIT uwzględniono dodatkowo składki na ubezpieczenia społeczne i zdrowotne, otrzymano już dodatni wpływ na rozmiary gospodarki nieformalnej. Autor podsumowując uzyskane wyniki zauważa, że

${ }^{9}$ S.B. Aruoba, Informal Sector, Government Policy and Institutions, Society for Economic Dynamics, Working Paper, 2010, vol. 324.

${ }^{10}$ G. Gołębiowski, Zjawisko szarej strefy z uwzględnieniem gospodarki polskiej, „Współczesna Ekonomia" 2007, nr 1, s. 17-28.

${ }^{11}$ S. Cichocki, Rozmiary ,szarej strefy” w Polsce oraz ich zależność od polityki podatkowej $i$ sytuacji budżetu państwa w latach 1995-2006, http:/www.pseap.org/wordpress/seminaria/iedycja, 2008. 
szara strefa w Polsce charakteryzowała się dynamiką wzrostową po podniesieniu obciążeń podatkowych.

Przeprowadzony powyżej przegląd literatury prowadzi do wniosku, iż wpływ obciążeń podatkowych na rozmiary szarej strefy pozostaje niejednoznaczny. Konieczne wydają się zatem dalsze badania. Wyniki niektórych prac sugerują również konieczność rozbicia obciążeń podatkowych na elementy składowe - w szczególności na podatki pośrednie i bezpośrednie. Różne mogą być bowiem kanały wpływu poszczególnych rodzajów podatków na szarą gospodarkę. A. Buehn, R. Dell'Anno, i F. Schneider ${ }^{12}$ zwracają jeszcze uwagę na fakt występowania w niektórych krajach znacznej iluzji fiskalnej, która zniekształca rzeczywisty obraz obciążeń podatkowych.

\section{Badanie}

W niniejszym badaniu przeprowadzimy próbę weryfikacji hipotezy o zależności pomiędzy szarą strefą gospodarki a obciążeniami podatkowymi. Analizę przeprowadzimy dla łącznej stawki opodatkowania, jak i poszczególnych jej komponentów - podatków pośrednich (VAT, akcyza i innych podatków konsumpcyjnych) oraz podatków bezpośrednich (PIT, CIT). Sprawdzimy, czy różne są kanały zależności pomiędzy poszczególnymi formami opodatkowania a wielkością szarej strefy. Dodatkowo zbadamy relację pomiędzy łącznymi przychodami podatkowymi a gospodarką nieformalną. W tym celu zastosujemy prostą analizę statystyczną (głównie pomiar korelacji) pomiędzy omówionymi zmiennymi. W badaniu skupimy się na krajach OECD, dlatego koniecznym staje się uwzględnienie wyników dotychczasowych badań nad szarą gospodarką w krajach rozwiniętych i uwzględnienie specyfiki tych krajów.

Staraliśmy się, aby dane wykorzystane w badaniu były jak najświeższe. W związku z tym szacunki szarej strefy zaczerpnięte zostały z pracy Schneidera. Przedstawiono w niej statystyki dla krajów OECD (jednak bez Chile, Islandii, Izraela, Korei Płd. i Meksyku) oraz dodatkowo dla Bułgarii, Cypru, Łotwy, Litwy, Malty, Rumunii i Chorwacji za lata 2003-2012. W pracy dokonamy analizy przekrojowej, $\mathrm{w}$ związku $\mathrm{z}$ tym uśredniliśmy powyższe wartości otrzymując przeciętne rozmiary szarej strefy w powyższych 36 krajach, co przedstawiono w tabeli 1 . Szacunki te wyrażone są w \% PKB.

Jako miernik opodatkowania wykorzystano World Tax Index (WTI) ${ }^{13}$. Jest to wskaźnik, który obejmuje ponad $95 \%$ łącznych obciążeń podatkowych danego państwa, których porównanie jest możliwe pomiędzy różnymi krajami.

${ }^{12}$ A. Buehn, R. Dell'Anno, i F. Schneider, Fiscal illusion and the shadow economy: Two sides of the same coin?, MPRA Paper 2012, no. 42531.

${ }^{13} \mathrm{http}: / / \mathrm{www}$. worldtaxindex.com/. 
Przeprowadzone szacunki WTI dotyczą 34 państw OECD w latach 2000-2011. Dodatkowo, autorzy dokonują rozbicia na poszczególne rodzaje podatków: PIT, CIT, VAT, PRO (Individual Property Taxes - podatki od własności) oraz OTC (Other Taxes on Consumption - pozostałe podatki konsumpcyjne, w tym m.in. akcyza). Zebrane dane, podobnie jak w przypadku szarej strefy, uśredniono za lata 2003-2011, otrzymując przeciętne wskaźniki podatkowe w 34 krajach. Zestawiając te dane z szacunkami szarej strefy, otrzymano bazę danych dla 29 krajów OECD.

Dodatkowo, jako miernik obciążenia podatkowego wykorzystano wielkość przychodów podatkowych $\mathrm{w}$ danym kraju wyrażonych jako \% PKB. Dane zaczerpnięte zostały z bazy danych Banku Światowego ${ }^{14}$, gdzie gromadzone są szacunki przychodów podatkowych (z wyłączeniem składek na ubezpieczenia społeczne) dla ponad 200 krajów za lata 1990-2011. Z powyższej bazy danych wybrano szacunki dla 36 krajów, dla których zebrano dane dotyczące szarej strefy gospodarki. Następnie wyznaczono przeciętną wysokość przychodów podatkowych w poszczególnych państwach, jako średnią arytmetyczną przychodów w latach 2003-2011. W ten sposób otrzymano szacunki przychodów podatkowych i rozmiarów szarej strefy dla 36 krajów.

\section{Wyniki analizy danych}

W celu sprawdzenia istnienia zależności pomiędzy szarą strefą a obciążeniami podatkowymi stworzyliśmy wykresy rozrzutu zmiennych. Analizę rozpoczęliśmy od mierników reprezentujących łączną wielkość opodatkowania w danym kraju, czyli WTI oraz łącznych przychodów podatkowych. W przypadku przychodów budżetowych nie widać było żadnej wyraźnej zależności $\mathrm{z}$ rozmiarami szarej strefy, co ilustruje rysunek 1.

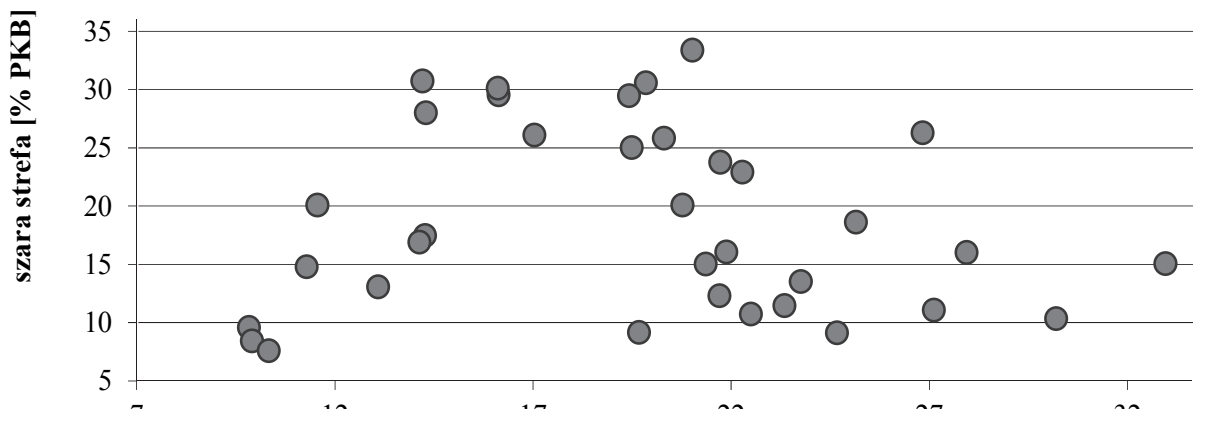

Rysunek 1. Zależność pomiędzy szarą strefą a przychodami podatkowymi Źródło: opracowanie własne (dotyczy rysunków 1-7).

\footnotetext{
${ }^{14}$ http://data.worldbank.org/indicator/GC.TAX.TOTL.GD.ZS/countries.
} 
Zdecydowanie wyraźniejszą, ale również słabą zależność dodatnią można zauważyć w przypadku relacji pomiędzy szarą strefą a World Tax Index.

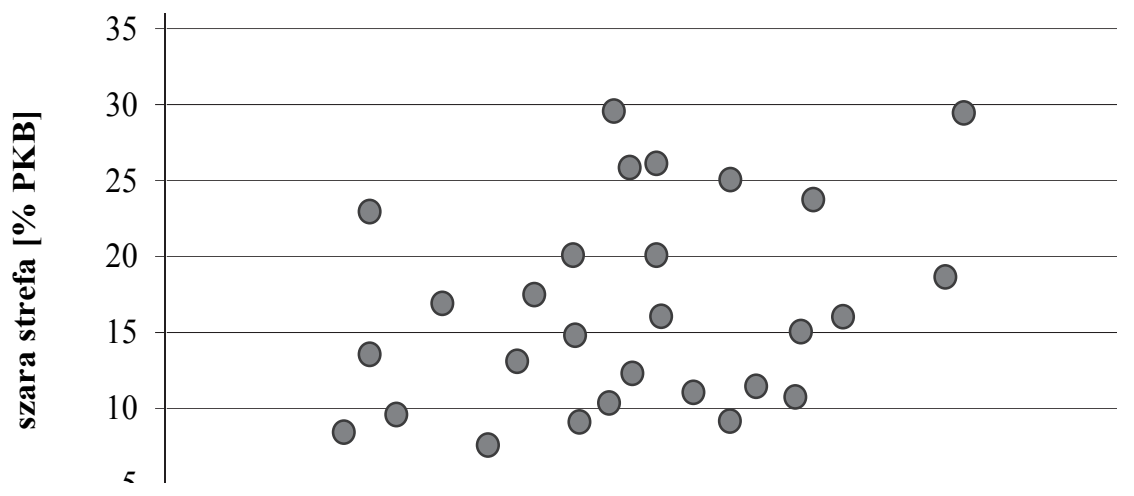

Rysunek 2. Zależność pomiędzy szarą strefą a WTI

W celu potwierdzenia wynikających z wykresów zależności dokonano pomiaru korelacji. W pierwszym przypadku otrzymano współczynnik na poziomie 0,032, co potwierdza brak istotnej zależności. Natomiast dla WTI współczynnik korelacji wyniósł 0,226 , co jest zgodne z literaturą ekonomiczną - wysokim rozmiarom obciążeń podatkowych towarzyszą wysokie poziomy szarej gospodarki. Zastanawiający jest jedynie stosunkowo niski poziom współczynnika korelacji, który sugeruje relatywnie słabą zależność. W związku z tym koniecznym wydaje się zbadanie kierunku zależności pomiędzy szarą strefą a poszczególnymi podatkami ze względu na możliwe znoszenie się ich wpływu, co sugerował m.in. G. Gołębiowski ${ }^{15}$ oraz S. Cichocki ${ }^{16}$.

Wykresy rozrzutu dla CIT, PIT, VAT, PRO oraz OCT przedstawiono odpowiednio na rysunkach $3,4,5,67$.

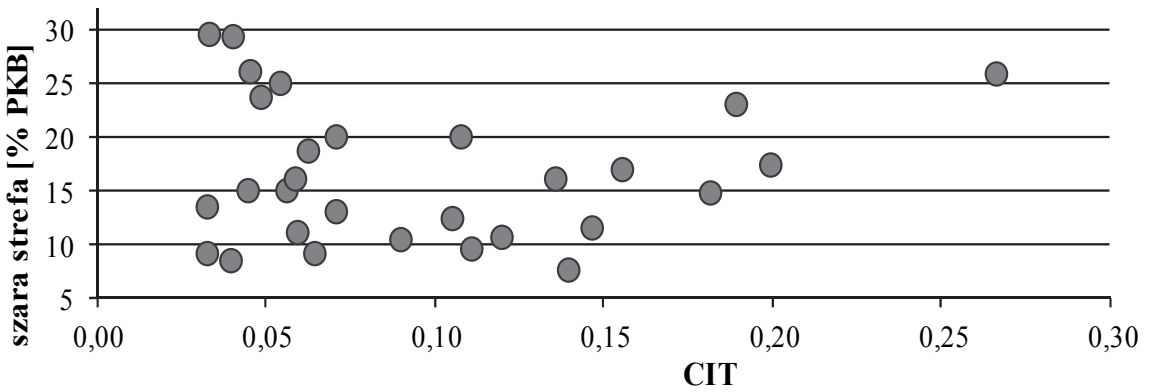

Rysunek 3. Zależność pomiędzy szarą strefą a CIT

${ }^{15}$ G. Gołębiowski, Zjawisko szarej strefy...

${ }^{16}$ S. Cichocki, Rozmiary ,,szarej strefy" w Polsce.... 


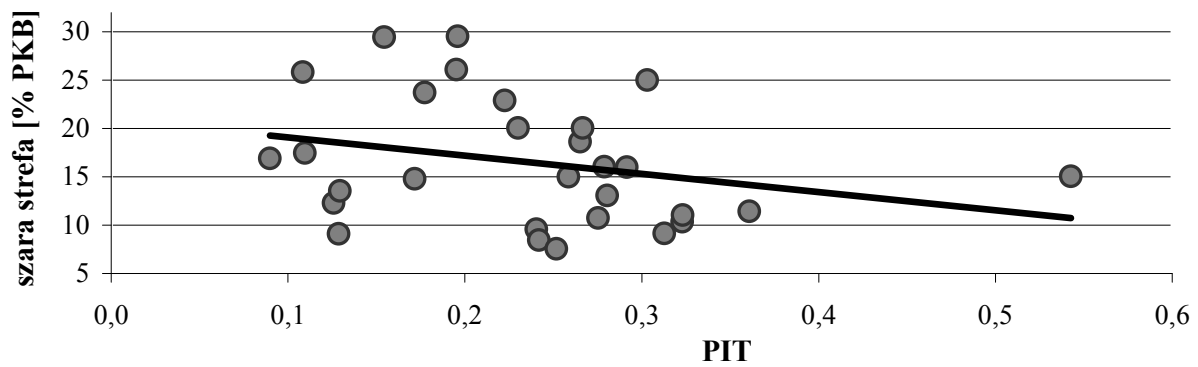

Rysunek 4. Zależność pomiędzy szarą strefą a PIT

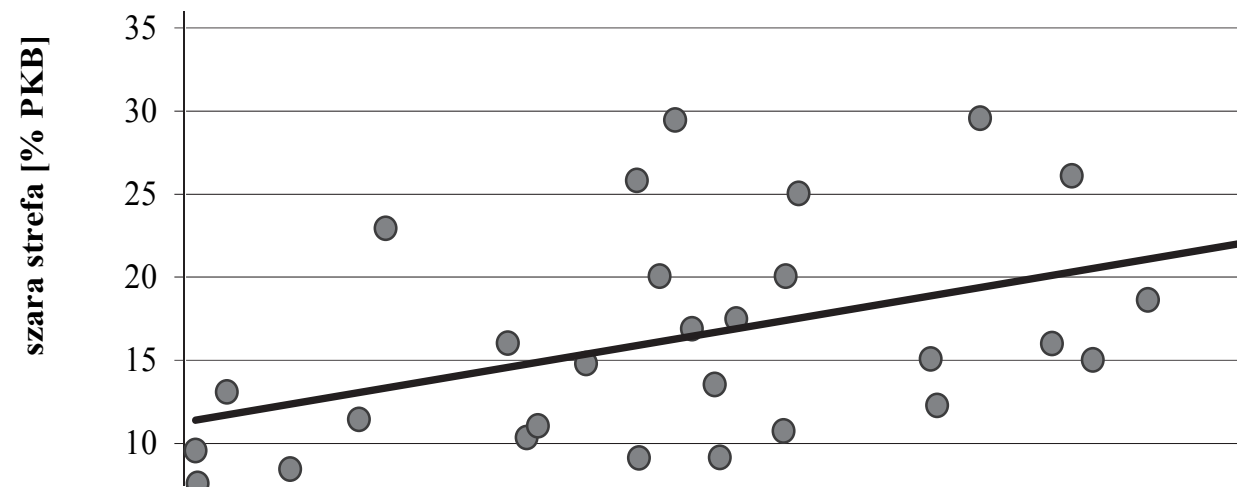

Rysunek 5. Zależność pomiędzy szarą strefą a VAT

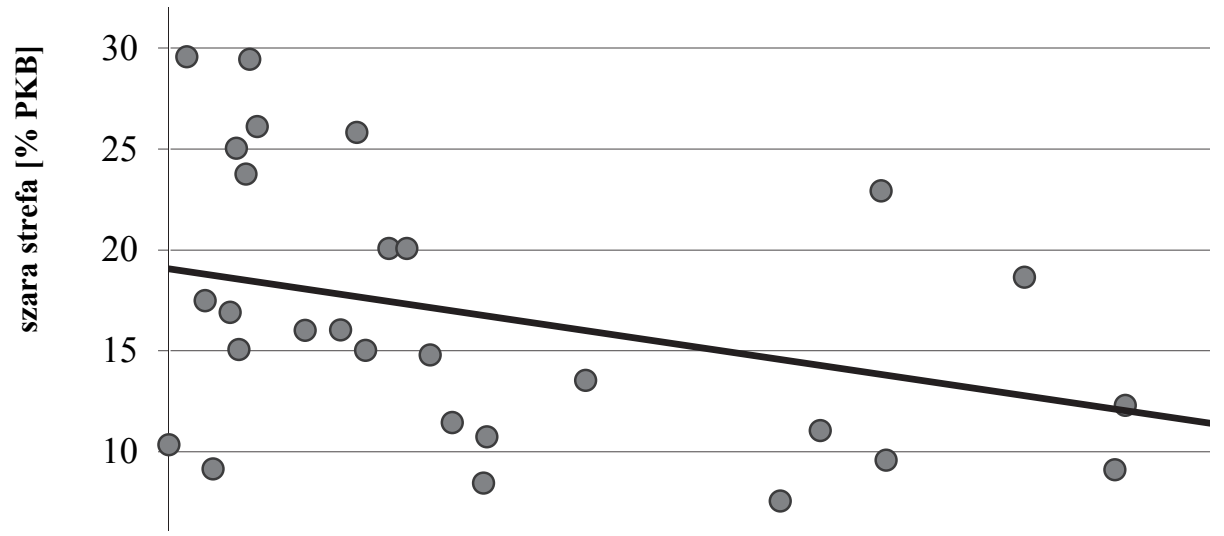

Rysunek 6. Zależność pomiędzy szarą strefą a PRO 


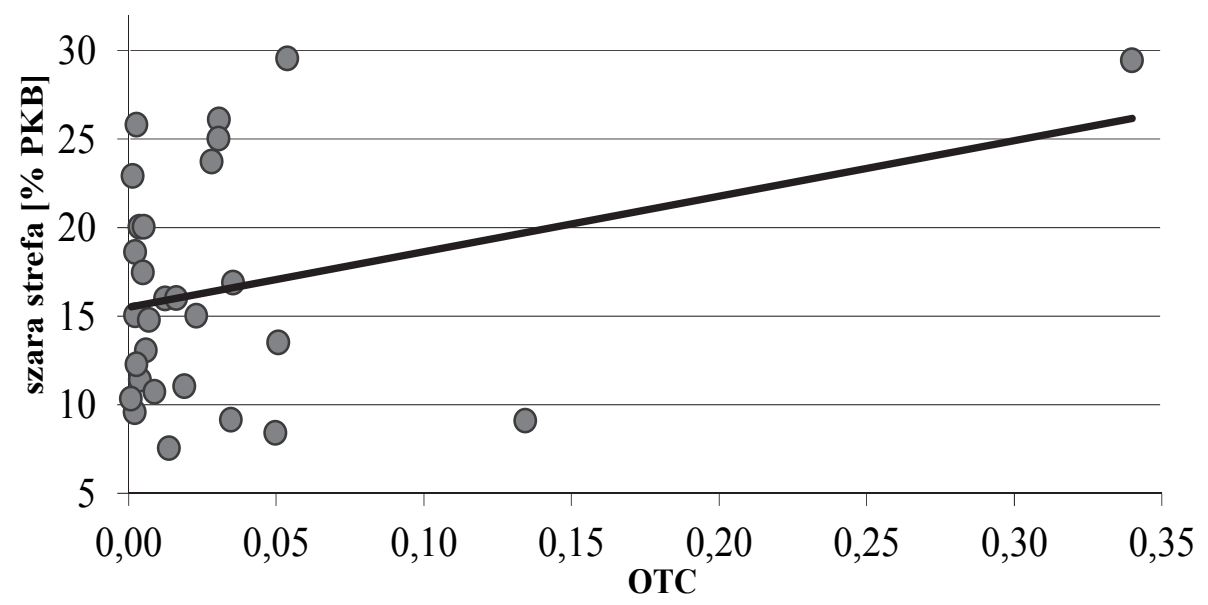

Rysunek 7. Zależność pomiędzy szarą strefą a OTC

W przypadku niektórych rodzajów opodatkowania możemy zauważyć wyraźną zależność dodatnią, a w innych ujemną. Najbardziej widoczną relację odnotowano dla stawek podatku VAT i PRO. Obliczone wartości współczynników korelacji z poziomem szarej strefy dla każdego rodzaju podatku przedstawiono w tabeli 2, zaś pomiędzy poszczególnymi podatkami w tabeli 3.

Tabela 2. Współczynniki korelacji pomiędzy przeciętnym poziomem szarej strefy a przeciętnymi obciążeniami podatkowymi mierzonymi różnymi rodzajami opodatkowania dla (1) 29 krajów

OECD, (2) 36 krajów OECD

\begin{tabular}{|c|c|c|c|c|c|c|c|}
\hline $\begin{array}{c}\text { Współczynnik } \\
\text { korelacji }\end{array}$ & WTI & CIT & PIT & VAT & PRO & OTC & $\begin{array}{c}\text { Dochody } \\
\text { podatkowe }\end{array}$ \\
\hline Szara strefa & $\begin{array}{c}(1) \\
0,226\end{array}$ & $\begin{array}{c}(1) \\
0,017\end{array}$ & $\begin{array}{c}(1) \\
-0,276\end{array}$ & $\begin{array}{c}(1) \\
0,471\end{array}$ & $\begin{array}{c}(1) \\
-0,392\end{array}$ & $\begin{array}{c}(1) \\
0,313\end{array}$ & $\begin{array}{c}(2) \\
0,032\end{array}$ \\
\hline
\end{tabular}

Źródło: obliczenia własne (dotyczy tabel 2-5).

Analizując powyższe współczynniki możemy zauważyć, iż zależność pomiędzy PIT i PRO a rozmiarami szarej strefy jest ujemna, natomiast pomiędzy VAT i OTC a gospodarką nieformalną wyraźnie dodatnia.W przypadku CIT stwierdzono zaś brak istotnego związku. A zatem poszczególne typy podatków można podzielić na dwie grupy - podatki bezpośrednie i podatki pośrednie. W przypadku pierwszej z nich wysokim rozmiarom opodatkowania towarzyszą niskie poziomy szarej strefy, natomiast wysokim rozmiarom podatków pośrednich towarzyszą znaczne rozmiary gospodarki nieformalnej. Jak widać rodzaje związku opodatkowania z szarą strefą są różne i zależą od charakteru opodatkowania. 
Tabela 3. Współczynniki korelacji pomiędzy różnymi miernikami obciążenia podatkowego dla 29 krajów OECD

\begin{tabular}{|l|c|c|c|c|c|c|c|}
\hline $\begin{array}{c}\text { Współczynik } \\
\text { korelacji }\end{array}$ & WTI & CIT & PIT & VAT & PRO & OTC & $\begin{array}{c}\text { Dochody } \\
\text { podatkowe }\end{array}$ \\
\hline WTI & 1 & $-0,286$ & 0,546 & 0,570 & $-0,280$ & 0,191 & 0,591 \\
\hline CIT & $-0,286$ & 1 & $-0,264$ & $-0,363$ & $-0,031$ & $-0,352$ & $-0,249$ \\
\hline PIT & 0,546 & $-0,264$ & 1 & $-0,077$ & $-0,083$ & $-0,283$ & 0,428 \\
\hline VAT & 0,570 & $-0,363$ & $-0,077$ & 1 & $-0,366$ & 0,021 & 0,412 \\
\hline PRO & $-0,280$ & $-0,031$ & $-0,083$ & $-0,366$ & 1 & $-0,102$ & $-0,094$ \\
\hline OTC & 0,191 & $-0,352$ & $-0,283$ & 0,021 & $-0,102$ & 1 & $-0,009$ \\
\hline $\begin{array}{l}\text { Dochody } \\
\text { podatkowe }\end{array}$ & 0,591 & $-0,249$ & 0,428 & 0,412 & $-0,094$ & $-0,009$ & 1 \\
\hline
\end{tabular}

W związku z otrzymanymi wynikami powstaje pytanie o przyczynę różnorodnego wpływu odmiennego opodatkowania na rozmiary szarej strefy. Zgodnie z intuicją spodziewać się mogliśmy raczej zależności odwrotnej - to wysokim rozmiarom podatków bezpośrednich powinny towarzyszyć wysokie rozmiary szarej strefy, zaś wysokim poziomom podatków pośrednich niskie rozmiary szarej strefy. Zgodnie bowiem $\mathrm{z}$ teorią ekonomiczną, podatki bezpośrednie są dużo bardziej zauważalne przez podmioty gospodarcze. Podatki pośrednie często stanowią bowiem opodatkowanie ukryte, którego część społeczeństwa nie jest świadoma. Natomiast nasze wyniki sugerują zależność odwrotną. Można to próbować wyjaśnić specyficzną próbą, którą poddaliśmy analizie. Badaliśmy bowiem jedynie kraje OECD, a więc kraje postrzegane jako rozwinięte. Zgodnie ze spostrzeżeniami F. Schneidera ${ }^{17}$ szara strefa ma odmienny charakter w krajach wysoko rozwiniętych i w rozwijających się. W krajach rozwiniętych (a więc w OECD) rozwinął się też wysoki poziom praworządności, efektywność wymiaru sprawiedliwości, jakość instytucji publicznych. W związku z tym działalność w szarej strefie polega głównie na dodatkowej aktywności gospodarczej (np. ukrywanie części produkcji w zarejestrowanym przedsiębiorstwie). Każde większe przejawy działalności nierejestrowanej zostałyby bowiem wykryte przed relatywnie efektywnie funkcjonujące organy kontroli. Natomiast w krajach rozwijających się wymiar sprawiedliwości, szeroko rozumiana praworządność nie zostały jeszcze wykształcone na takim poziomie jak w krajach rozwiniętych. W związku z tym często dochodzi do korupcji i różnego rodzaju nadużyć władzy. W takich krajach aktywność w szarej strefie ma często charakter podstawowy i stanowi główne źródło utrzymania podmiotów gospodarczych w niej działających.

\footnotetext{
${ }^{17}$ F. Schneider, Shadow Economies and Corruption...
} 
Wytłumaczenie otrzymanych wyników znaleźć można również w pracy A. Buehna, R. Dell'Anno, i F. Schneidera ${ }^{18}$. Zgodnie z koncepcją iluzji fiskalnej, rządzący mogą stosować pewne narzędzia polityki gospodarczej, które pozwalają im zataić rzeczywisty poziom obciążeń podatkowych. Jednym z nich jest zmiana struktury opodatkowania - zmniejszenie udziału podatków bezpośrednich przy zachowaniu obciążeń podatkowych na dotychczasowym poziomie kosztem zwiększenia udziału podatków pośrednich, które są mniej zauważalne przez społeczeństwo. Autorzy zwracają jednak uwagę na fakt, iż w krajach o wysokim wykształceniu przeciętnym społeczeństwa (a więc i w krajach OECD), iluzja fiskalna jest zdecydowanie mniej skuteczna i może nie zadziałać. Może to thumaczyć silną reakcję szarej strefy na zmianę podatków VAT i OTC.

Niezgodne $\mathrm{z}$ teorią wyniki skłaniają do sformułowania hipotezy o nieliniowym wpływie wysokości obciążeń podatkowych na szarą strefę gospodarki. W tym celu analizowane kraje podzielono na dwie grupy - kraje o relatywnie wysokim $^{19}$ i niskim $^{20}$ przeciętnym opodatkowaniu.

Wśród krajów o niskim przeciętnym poziomie opodatkowania (15 krajów o najniższym wskaźniku WTI) zauważono następującą korelację pomiędzy poziomem szarej strefy a poszczególnymi rodzajami podatków:

Tabela 4. Współczynniki korelacji pomiędzy przeciętną szarą strefą a przeciętnymi obciążeniami podatkowymi mierzonymi różnymi rodzajami opodatkowania dla 15 krajów OECD o relatywnie niskim wskaźniku WTI

\begin{tabular}{|c|c|c|c|c|c|c|c|}
\hline $\begin{array}{c}\text { Współczynnik } \\
\text { korelacji }\end{array}$ & WTI & CIT & PIT & VAT & PRO & OTC & $\begin{array}{c}\text { Dochody } \\
\text { podatkowe }\end{array}$ \\
\hline Szara strefa & 0,290 & 0,335 & $-0,292$ & 0,534 & $-0,410$ & $-0,167$ & 0,140 \\
\hline
\end{tabular}

Natomiast dla pozostałych 14 krajów o relatywnie wysokim wskaźniku WTI otrzymano następujące oszacowania współczynników korelacji:

Tabela 5. Współczynniki korelacji pomiędzy przeciętną szarą strefą a przeciętnymi obciążeniami podatkowymi mierzonymi różnymi rodzajami opodatkowania dla 15 krajów OECD o relatywnie niskim wskaźniku WTI

\begin{tabular}{|c|c|c|c|c|c|c|c|}
\hline $\begin{array}{c}\text { Współczynnik } \\
\text { korelacji }\end{array}$ & WTI & CIT & PIT & VAT & PRO & OTC & $\begin{array}{c}\text { Dochody } \\
\text { podatkowe }\end{array}$ \\
\hline Szara strefa & 0,049 & $-0,470$ & $-0,566$ & 0,360 & $-0,294$ & 0,559 & $-0,413$ \\
\hline
\end{tabular}

${ }^{18}$ A. Buehn, R. Dell'Anno, i F. Schneider, Fiscal illusion...

${ }^{19}$ Te kraje to Polska, Hiszpania, Szwecja, Wielka Brytania, Austria, Słowenia, Australia, Holandia, Finlandia, Węgry, Norwegia, Belgia, Turcja, Dania (WTI powyżej 0,53).

${ }^{20}$ Te kraje to Szwajcaria, Irlandia, Włochy, Japonia, Słowacja, Stany Zjednoczone, Kanada, Czechy, Portugalia, Niemcy, Luksemburg, Nowa Zelandia, Estonia, Grecja, Francja (WTI poniżej $0,52)$. 
W przypadku krajów należących do grupy o relatywnie wysokim wskaźniku WTI zauważyć możemy istotną zmianę, która zaszła w przypadku podatków bezpośrednich. Podatek CIT, który do tej pozostawał bez związku z szarą strefą, wykazuje wyraźną ujemną zależność na poziomie $-0,56$. Znacznemu podniesieniu uległ też współczynnik korelacji dla podatku PIT do -0,566. Ujemną wartość utrzymał też współczynnik korelacji w przypadku trzeciego rodzaju podatku bezpośredniego - PRO, choć uległ nieznacznemu obniżeniu. A zatem w przypadku tej grupy krajów zauważyć możemy wyraźną zależność ujemną pomiędzy rozmiarami szarej strefy a poziomem podatków bezpośrednich. Natomiast współczynniki korelacji dla podatków pośrednich zachowały swoje znaki, nastąpił jedynie nieznaczny spadek wartości współczynnika dla podatku VAT i znaczny wzrost dla podatku OTC (do 0,559$)$. Ostatecznie wyniki otrzymane dla krajów o relatywnie wysokim poziomie opodatkowania potwierdzają dotychczasowe rezultaty o ujemnej zależności pomiędzy szarą strefą a podatkami bezpośrednimi i dodatnią z podatkami pośrednimi. Warto tu jeszcze zwrócić uwagę na fakt, iż pojawił się silny ujemny związek szarej strefy z dochodami podatkowymi, prawdopodobnie ze względu na silny wpływ podatków bezpośrednich.

Natomiast dla krajów o niższym przeciętnym opodatkowaniu otrzymano zupełnie inne wyniki. Niektóre z podatków bezpośrednich zachowały swoje dotychczasowe kierunki zależności (współczynnik korelacji dla PIT i PRO pozostał ujemny na prawie niezmienionym poziomie), jednak pojawiła się dodatnia zależność pomiędzy podatkiem CIT a szarą strefą na poziomie 0,335. A zatem wpływ podatków bezpośrednich pozostaje nieokreślony. Podobnie w przypadku podatków pośrednich współczynnik korelacji dla podatku VAT pozostał dodatni na relatywnie wysokim poziomie 0,534 , jednak znacznie zmalał wskaźnik dla OTC do poziomu, w którym związek z szarą strefą przestał występować. Podsumowując powyższe rozważania, w przypadku krajów o relatywnie niskim poziomie opodatkowania, trudno jednoznacznie określić wpływ podatków pośrednich i bezpośrednich na szarą strefę gospodarki.

Otrzymane wyniki potwierdzają przypuszczenie o istnieniu nieliniowej zależności pomiędzy podatkami pośrednimi i bezpośrednimi a szarą strefą. Postać tej nieliniowej zależności będzie przedmiotem dalszych badań autorki niniejszej pracy. Szczególnie istotne wydaje rozszerzenie próby o kraje spoza OECD, co podniesie wiarygodność dotychczasowych analiz i pozwoli na przeprowadzenie dalszych badań z uwzględnieniem m.in. podziału próby na kraje rozwinięte i rozwijające się.

\section{Zakończenie}

W pracy przeprowadzona została analiza statystycznej zależności pomiędzy szarą strefą a obciążeniami podatkowymi. Dokonaliśmy przy tym rozróżnienia na różne rodzaje podatków - podatki bezpośrednie: PIT, CIT i PRO oraz podatki 
pośrednie - VAT i OTC. Uzyskane wartości współczynników korelacji sugerują, że $\mathrm{z}$ wysokimi rozmiarami podatków pośrednich wiążą się wysokie rozmiary szarej strefy, zaś wysokim poziomom podatków bezpośrednich towarzyszą niskie rozmiary szarej strefy. Uzyskane zależności, choć zaskakujące i niezgodne $\mathrm{z}$ intuicją ekonomiczną, mogą znaleźć uzasadnienie w specyfice szarej strefy występujące w krajach OECD. Można też próbować wyjaśnić je za pomocą zjawiska iluzji fiskalnej, która nie występuje w krajach wysoko rozwiniętych.

Jednak najlepszym chyba wytłumaczeniem jest występowanie nieliniowej zależności pomiędzy podatkami pośrednimi i bezpośrednimi a szarą strefą. Przypuszczenie to zdają się potwierdzać analizy polegające na podziale próby na dwie grupy - na kraje o wysokim i niskim przeciętnym opodatkowaniu. Współczynniki korelacji wyznaczone dla poszczególnych grup dają bowiem odmienne rezultaty.

Konieczne wydają się dalsze badania, a zwłaszcza analiza charakteru szarej strefy w krajach rozwiniętych i rozwijających. Ciekawe może być też podzielenie próby na kraje o wysokiej i niskiej iluzji fiskalnej i zbadanie wpływu zmian podatków w poszczególnych krajach na zmiany rozmiarów szarej strefy. W obu przypadkach niezbędne jest jednak rozszerzenie próby o kolejne kraje spoza OECD. Autorka niniejszej pracy ma jednak nadzieję, że przeprowadzona przez nią analiza dostarczyła ważnych informacji dotyczących zjawiska szarej strefy gospodarki i stanowi istotny zalążek dalszych badań.

\section{Literatura}

Aruoba S.B., Informal Sector, Government Policy and Institutions, Society for Economic Dynamics, Working Paper, 2010, vol. 324.

Buehn A., Dell'Anno R., Schneider F., Fiscal illusion and the shadow economy: Two sides of the same coin?, MPRA Paper 2012, no. 42531.

Buehn A., Montenegro C. E., Schneider F., Shadow economies all over the World. New estimates for 162 countries from 1999 to 2007, PRWP 2010, no. 5356.

Cichocki S., Rozmiary „szarej strefy” w Polsce oraz ich zależność od polityki podatkowej i sytuacji budżetu państwa w latach 1995-2006, http://www.pseap.org/wordpress/seminaria/iedycja, 2008.

Gołębiowski G., Zjawisko szarej strefy z uwzględnieniem gospodarki polskiej, „Współczesna Ekonomia" 2007, nr 1.

Kabaj M., Praca nierejestrowana we wspótczesnej literaturze ekonomicznej, „Polityka Społeczna” 2009, nr 10.

Kozyra-Cybulska M., Molenda A., Wojnar E., Zielański M., Badanie warunków i jakości życia oraz zachowań ekonomicznych $w$ gospodarstwach domowych, Działalność nierejestrowana, PTS, Rzeszów 2010.

Patera K. i in., Projekt Przyczyny pracy nierejestrowanej, jej skala, charakter i skutki społeczne, CBOS, IPiSS, Warszawa 2007.

Schneider F., Shadow economies and corruption all over the World: What do we really know?, Kiel Institute for the World Economy ,Economics Discussion Papers 2007, no. 9 . 
Schneider, F., The shadow economy and shadow economy labor force: What do we (not) know?, „Forschungsinstitut zur Zukunft der Arbeit” 2011, Nr. 5769.

Smuga T. i in., Metodologia badań szarej strefy na rynku ustug turystycznych, Instytut Koniunktury i Cen Handlu Zagranicznego, Warszawa 2005.

Special Eurobarometer, Undeclared Work in the European Union, European Commission, Brussels 2007.

http://www.worldtaxindex.com/.

http://data.worldbank.org/indicator/GC.TAX.TOTL.GD.ZS/countries.

\section{Streszczenie}

W pracy dokonana została analiza statystycznej zależności pomiędzy różnymi rodzajami opodatkowania a wielkością szarej strefy gospodarki w krajach OECD. Okazuje się, że relacja pomiędzy przeciętnym łącznym obciążeniem podatkowym a gospodarką nieformalną jest dodatnia lub nie występuje w ogóle. Wysokim poziomom podatków pośrednich towarzyszą wysokie rozmiary szarej strefy, zaś z wysokimi podatkami bezpośrednim są związane niskie rozmiary gospodarki nieformalnej. Przypuszczać zatem należy, iż mamy tu do czynienia z nieliniową zależnością.

\section{Summary}

\section{RELATIONSHIP BETWEEN SIZE OF INFORMAL SECTOR AND TAXES. CROSS-SECTION ANALYSIS FOR OECD COUNTRIES}

Paper contains statistical analysis of relationship between different types of taxation and average size of informal sector in OECD countries. Analysis shows that correlation between average tax burden and size of informal sector in slightly positive or does not exist. Use of different types of taxes leads to significant correlations - with higher levels of indirect taxes higher levels of informal sector are related, higher levels of direct taxes are correlated with lower levels of informal sector. It implies conclusion of nonlinear relationship between variables. 